\title{
Propagation of Atlantic Ocean swells in the north Indian Ocean: a case study
}

\author{
S. V. Samiksha ${ }^{1}$, P. Vethamony ${ }^{1}$, V. M. Aboobacker ${ }^{2}$, and R. Rashmi ${ }^{1}$ \\ ${ }^{1}$ National Institute of Oceanography, Dona Paula, Goa - 403004, India \\ ${ }^{2}$ Tropical Marine Science Institute (TMSI), National University of Singapore, Singapore
}

Correspondence to: P. Vethamony (mony@nio.org)

Received: 16 May 2012 - Revised: 13 September 2012 - Accepted: 30 October 2012 - Published: 7 December 2012

\begin{abstract}
An analysis of altimeter significant wave height data of May 2007 revealed the occurrence of an extreme weather event off southern tip of South Africa in the Atlantic Ocean, and generation of a series of very high swells at $40^{\circ} \mathrm{S}$. These swells propagated towards northeast and broke over La Réunion island in the Indian Ocean on 12 May 2007. The wave model WAVEWATCH III was used to study the propagation of these swells in the Indian Ocean. The model was validated for the Indian Ocean using moored buoy data at 12 locations and merged altimeter wave data. The wave model accurately reproduced the event of May 2007. Swell heights, of the order of $15.0 \mathrm{~m}$, at the generation area reduced to $6.0 \mathrm{~m}$ near La Réunion island. This study shows that the swells generated in the Roaring Forties of the Atlantic Ocean (between $15^{\circ}$ to $80^{\circ} \mathrm{E}$ longitude) propagate in the NE/NNE direction towards the north Indian Ocean, and wave characteristics of the Arabian Sea are least influenced compared to that of Bay of Bengal, when swells from the Atlantic Ocean enter the Indian Ocean. The double peak spectrum extracted for the Bay of Bengal indicates that one of the peaks is due to swells generated off southern tip of South Africa.
\end{abstract}

\section{Introduction}

Accurate wave information, including waves of extreme weather events, is very essential for a wide range of research and engineering applications. Wave statistics derived from point measurements were considered for obtaining reliable local wave climate in the past. However, these measurements are not sufficient to describe the regional wave patterns over a long period of time. This emphasizes the need to work on wave models driven by wind fields obtained from satellites measurements or models. Third-generation wave models are capable of predicting the waves reasonably well, and the accuracies can be still improved with appropriate representation of extremely complex physical processes of wind generated waves (Vledder, 2001; Polnikov et al., 2007). Thirdgeneration models such as WAM (WAMDI Group, 1988) and WAVEWATCH III (Tolman, 1999) are widely applied for global as well as regional ocean state forecasts. The components of source function are used without prior restrictions on the spectral shape (Tolman, 1996). The shallow water wave model SWAN (SWAMP, 1985) has been designed specifically for coastal wave prediction, and it is utilized at several coastal regions around the world.

Francis and Stratton (1990) used altimeter wind speeds to provide information on the distribution of energy within the wave spectrum. Lionello et al. (1992) assimilated altimeter wave data in a third-generation wave model. Wave prediction studies have been carried out for the Indian Ocean region using scatterometer winds (Bhatt et al., 2005, 2006; Vethamony et al., 2006; Swain et al., 2004; Muraleedharan et al., 2009). For the coastal regions of India (e.g. Paradip coast), nearshore wave parameters have been estimated by Aboobacker et al. (2009) using wave model. Sensitivity study of the input forcing, as well as assimilation experiments, for the coastal regions of India has been performed by Kumar et al. (2009). Vethamony et al. (2000) used ECMWF (European Centre for Medium-Range Weather Forecast) winds in a second-generation wave model to hindcast waves for the north Indian Ocean.

Studies on swells and their propagation in the world oceans have been of great interest to many researchers over the decades. Munk (1947) made an attempt to track the storms by using forerunners of the swells. Barber and 
Ursell (1948) measured frequency spectra of ocean waves in order to develop a reliable method for predicting amplitude and period of wind waves and swell from meteorological charts and forecasts. Snodgrass (1966) focused on the evolution of the swell energy along the propagation direction in the North Atlantic Ocean. Studies conducted over the last few decades have expanded these initial insights, revealing that the presence of swells affects several important processes at the air-sea interface such as the modulation, blockage and suppression of short period wind-generated waves. Hanson and Phillips (1999) investigated the wind sea growth and dissipation in a swell-dominated, open ocean environment to explore the use of wave parameters in air-sea process modelling.

Chen et al. (2002) analyzed the available simultaneous measurements from National Aeronautics and Space Administration (NASA) satellite sensors, the TOPEX altimeter, the NSCAT and QuikSCAT scatterometers and produced global maps of swell and wind sea climate. The study explained that there are three well-defined swell-dominated zones in the tropical areas of Pacific, Atlantic and Indian oceans. The persistent, strong winds over the Southern Ocean generate high waves that travel thousands of kilometers to the Indian Ocean as large swell component (Alves, 2006). These swells, on entering the Indian Ocean region, contribute to the total wave height of the surface waves. Ardhuin et al. (2009) provided an accurate estimation of dissipation rate of swell energy across the oceans. Further, Ardhuin et al. (2010) proposed a set of parameterization for the dissipation source terms of the wave energy balance equation based on known properties of swell dissipation and wave breaking statistics.

The generation and growing processes of wind seas have been the main focus in the development of wave models for forecasting purposes till recently. There has been a renewed interest in the study of swells particularly related to their propagation and attenuation (Alves, 2006; WISE, 2007; Ardhuin et al., 2009). It has been shown that swell decay rates are related to a reverse momentum flux process (Donelan et al., 1997; Grachev and Fairall, 2001), occurring as a swell performs work on the overlying atmosphere (Semedo et al., 2009). The study by Bhowmick et al. (2011) shows that the Indian Ocean is dominated by swells of considerable amplitudes. These swells arrive from the Southern Ocean during most part of the year and can grow significantly under the influence of strong winds such as storms. The study further suggests that the swells arriving at the north Indian Ocean during early or mid-May carry unique signatures of approaching monsoon. In the pre-monsoon months of April and May, the significant wave heights in the north Indian Ocean are relatively low in the range of $0.5-1 \mathrm{~m}$. However, during southwest monsoon (June-September), the swells of larger amplitudes start propagating in the Indian Ocean from the Southern Ocean, and the significant wave height increases to approximately $2.0-3.0 \mathrm{~m}$.
In the present study, the wave model WAVEWATCH III (hereinafter referred to as WW III) has been used to simulate the waves in the Indian Ocean. WW III (Tolman, 1997, 1998a, b, 2002a, b, 2003) is a fully spectral third-generation ocean wind-wave model, developed for the regional sea wave prediction at the Ocean Modeling Branch of the Environmental Modeling Center of the National Centers for Environmental Prediction (NCEP), USA. The present study aims at validating WW III for the Indian Ocean and understanding the characteristics of swells coming from the Atlantic Ocean into the Indian Ocean and their propagation in the north Indian Ocean (the Arabian Sea and the Bay of Bengal). For this purpose, a case study of swells generated in the Atlantic Ocean (near $40^{\circ} \mathrm{S}$ off South Africa) during an extreme weather event, in May 2007, has been taken up and collocated satellite data and modelling results have been used.

\section{Materials and methods}

\subsection{Data used}

The model domain used for the present study is shown in Fig. 1a. The moored buoy network established by the National Institute of Ocean Technology (NIOT), Chennai, India, under the Ministry of Earth Sciences (MoES), India, provided in-situ wave observations in the Indian Ocean for validating the WW III model results. Measured data of 12 locations (Fig. 1b), representing both the Arabian Sea and the Bay of Bengal, have been used. The data were measured at the rate of $1 \mathrm{~Hz}$ for $17 \mathrm{~min}$ at every 3-h duration. The processor on the buoy applies wave analysis software, which uses a fast Fourier transform on the wave record to obtain the power spectrum. Both directional and non-directional analyses are carried out to calculate a range of wave parameters. In the wave spectrum, the frequency range between 0.04 and $0.10 \mathrm{~Hz}$ is considered low-frequency (swell) components and between 0.10 and $0.50 \mathrm{~Hz}$ is considered high-frequency (sea) components (Rajesh et al., 2009).

The altimeter significant wave height $\left(H_{\mathrm{s}}\right)$ data are obtained from the IFREMER CERSAT altimeter $H_{\mathrm{s}}$ database. The database is constructed using the Geophysical Data Records (GDR) for each altimeter, and correcting $H_{\mathrm{s}}$ measurements according to previous studies. The database includes altimeter significant wave heights of $16-\mathrm{yr}$ period from the six altimeter missions ERS 1\&2, TOPEX/Poseidon, GEOSAT Follow-ON (GFO) (Naval Oceanographic Office, 2002), Jason-1 (Picot et al., 2003) and ENVISAT (ESA, 2002). Each altimeter data product has specific characteristics (format, flags), and, in order to facilitate the access to altimeter $H_{\mathrm{s}}$ measurements, data were extracted from the original products, screened according to quality flag values, corrected and gathered into homogeneous daily data files. Various quality flags applied to different altimeter datasets are detailed in Queffeulou et al. (2003, 2004). 

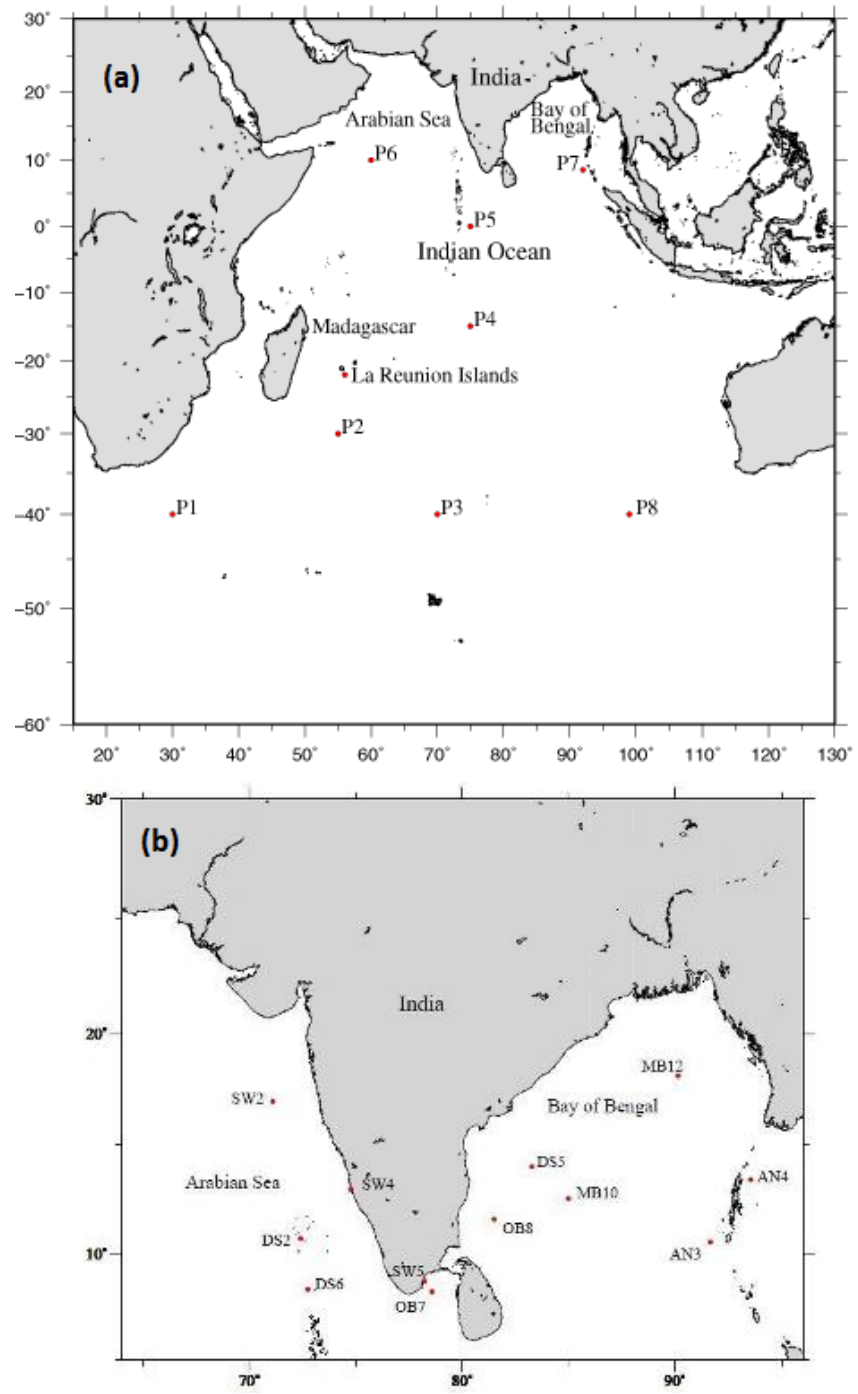

Fig. 1. (a) Model domain and selected points in the Indian Ocean for studying the propagation of swells during 2007 (b) Buoy measurement locations (2006).

Accurate wind data are needed for better wave prediction especially along the coastal region. Identifying the appropriate wind data with sufficient spatio-temporal resolution over a larger spatio-temporal scale is a major task which greatly determines the reliability and accuracy of wave model results. Winds used as input to the model are NCEP Reanalysis winds ( $u$ and $v$ components) available for 6 hourly interval and in $2.5^{\circ} \times 2.5^{\circ}$ grids (Kalnay et al, 1996). The wind data are further interpolated to $1^{\circ} \times 1^{\circ}$ for all the model simulations. The comparison of NCEP winds with buoy winds at two locations - DS2 (Arabian Sea) and DS5 (Bay of Bengal) - is given in Fig. 2, and the comparison shows the reliability of reanalysis winds (NCEP winds) in the wave model (WW III).

\subsection{Methodology}

WW III solves the spectral action density balance equation for wave number-direction spectra. The growth, refraction and decay of each component of the complete sea state for each specific frequency and direction are solved, giving complete and realistic characteristics of the transient wave field. The physical processes included in the model are refraction and straining of the wave field due to temporal and spatial variations of mean water depth and mean current, wave growth and decay due to the actions of wind, nonlinear resonant interactions, dissipation by white-capping and bottom friction. Details of the WW III model can be found in Tolman (1999).

The bathymetry of the study area is prepared using the ETOPO2 (Earth Topography $2 \mathrm{~min}$ ) obtained from the National Geophysical Data Centre, USA. The complex variation in the bathymetry calls for high spatial resolution in the model. We have tested the performance of the model for the following three grid sizes: $0.25^{\circ} \times 0.25^{\circ}, 0.5^{\circ} \times 0.5^{\circ}$ and $1.0^{\circ} \times 1.0^{\circ}$. The accuracy of simulated wave parameters improved when we considered either $0.25^{\circ} \times 0.25^{\circ}$ or $0.5^{\circ} \times 0.5^{\circ}$ grid size compared to $1.0^{\circ} \times 1.0^{\circ}$ grid. Accuracy is found to be the same for both $0.25^{\circ} \times 0.25^{\circ}$ and $0.5^{\circ} \times 0.5^{\circ}$ grid sizes, but as the computational time is higher for $0.25^{\circ} \times 0.25^{\circ}$ grid, we have therefore run the model with $0.5^{\circ} \times 0.5^{\circ}$ grid.

Most of the wave models could simulate the average wave parameters to an agreeable extent, but reliable simulation of swell components remains as a major limiting factor. Recently, for the Indian Ocean wave modelling, sensitivity analyses were carried out by Bhowmick et al. (2011) for WAM model and Aboobacker et al. (2011) for the MIKE 21 model. Hence, we have done the sensitivity analysis for WAVEWATCH III by taking the southern boundary up to $60^{\circ} \mathrm{S}$. In this study, we have done several model experiments, keeping the southern boundary at $40,50,60$ and $70^{\circ} \mathrm{S}$. However, we could not find any change in the wave parameters when the southern boundary was extended to south of $60^{\circ} \mathrm{S}$. Same was the case, when the domain was extended to west of $15^{\circ} \mathrm{E}$ and east of $120^{\circ} \mathrm{E}$. Hence, we considered the model domain bounded by latitudes $60^{\circ} \mathrm{S}$ to $30^{\circ} \mathrm{N}$ and longitudes $15^{\circ} \mathrm{E}$ to $120^{\circ} \mathrm{E}$ for the present study (Fig. 1a). In the pre-processing, the NCEP winds were interpolated to the respective grids in the bathymetry. Wave growth was computed using the source terms to account for wind input, non-linear wave-wave interactions and whitecapping. The effects of depth-induced refraction and island shadowing/blocking are included in the wave propagation scenario (Tolman, 2003). Model simulations have been carried out for two years (2006-2007) and validated with the buoy measurements of 2006. Swell propagation from the Atlantic Ocean into the north Indian Ocean has been studied for the year 2007, particulary for an extreme weather event that happened in the same year. 


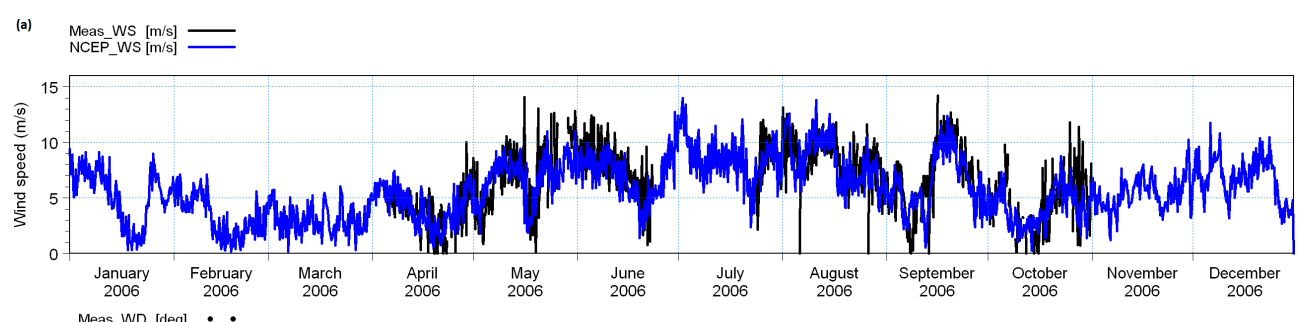

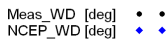

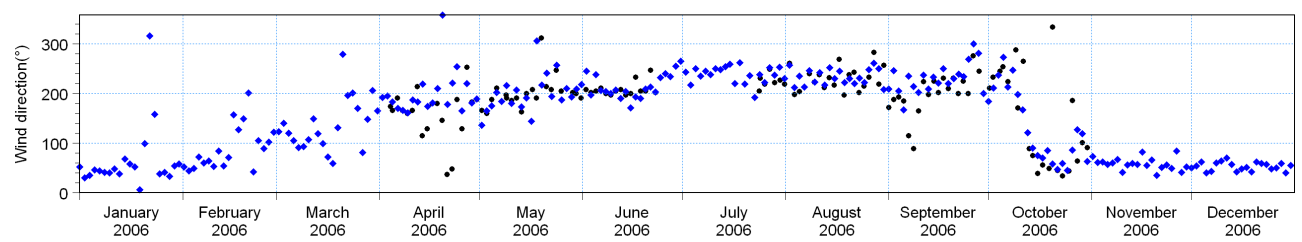

(b) Meas_WS $[\mathrm{m} / \mathrm{s}]=$

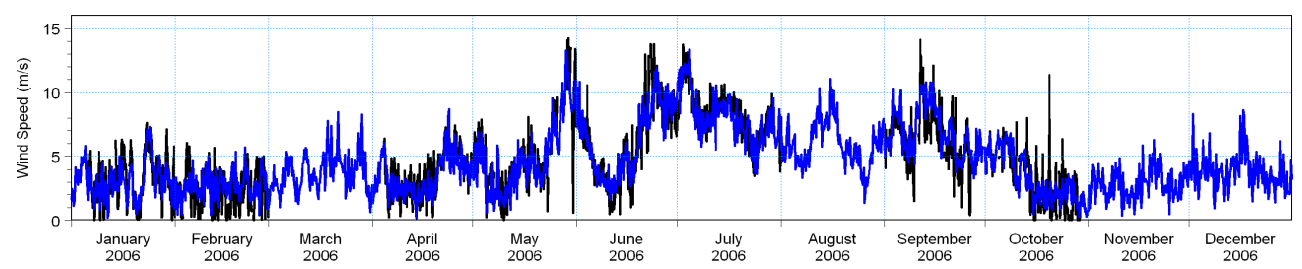

Meas WD [degl : :

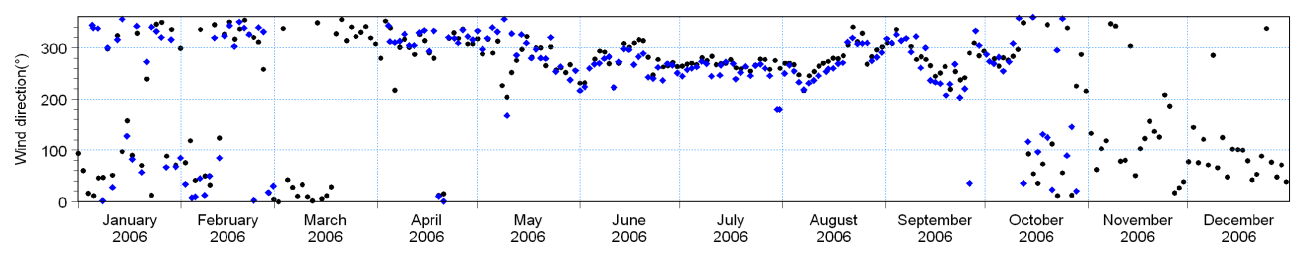

Fig. 2. Comparison of time series of NCEP winds (blue line) with buoy winds (black line) at two locations: (a) DS5 (Bay of Bengal) and (b) DS2 (Arabian Sea).

\section{Results and discussion}

\subsection{Model validation}

Selection of appropriate wind data with sufficient spatial and temporal resolutions over a large region is a major task which greatly determines the accuracy of model wave parameters. Accuracy of the wind input (NCEP Reanalysis) was tested by comparing the NCEP winds with the measured buoy winds at two locations (Fig. 2): DS2 (Arabian Sea) and DS5 (Bay of Bengal). Correlation coefficients of 0.87 (bias $=-0.02$, $\mathrm{rms}=1.5$ ) and 0.73 (bias $=-0.4, \mathrm{rms}=2.07$ ) were obtained for the wind speeds at DS2 and DS5. Seasonal variabilities, including monsoon conditions, are clearly evident in the NCEP winds as seen in the measurements. These give us the confidence to use NCEP winds for the analysis and model simulations.

Firstly, we wanted to see how far the model simulations can be brought very close to the observations. For this, we have run the model for different seasons, and analysed the wave characteristics of the Indian Ocean. To check the compatibility of the model for both deep water and shallow water, the model results were compared with buoy data at 12 locations (different depths) and also with altimeter wave heights. The results of validation experiments at two locations are presented in Figs. $3 a, b$ and 4 . The validation for deep water wave heights and wave directions (off Kakinada, off Pondicherry) is shown in Fig. 3a and b and shallow water wave heights and directions (off Tuticorin) in Fig. 4. Validation for wave period was not done due to unavailability of measured average wave period data. Altimeter wave heights presented in Figs. 3 and 4 also include validation. Tables 1 and 2 show the statistical comparison of model results with (i) measured data of all available buoys and (ii) collocated altimeter data obtained from Ifremer (CERSAT, 1996). Correlation coefficient between model and buoy $H_{\mathrm{s}}$ varies from 0.79 to 0.92 for deep water and 0.21 to 0.75 for shallow water (Table 1).

We have considered the frequency range from $0.025 \mathrm{~Hz}$ to $1.0 \mathrm{~Hz}$. As no signal was present in the high-frequency region, the model did not reproduce the same. As WAVEWATCH III is specifically meant for deep water, and not for shallow water, we receive good statistical results for deep 

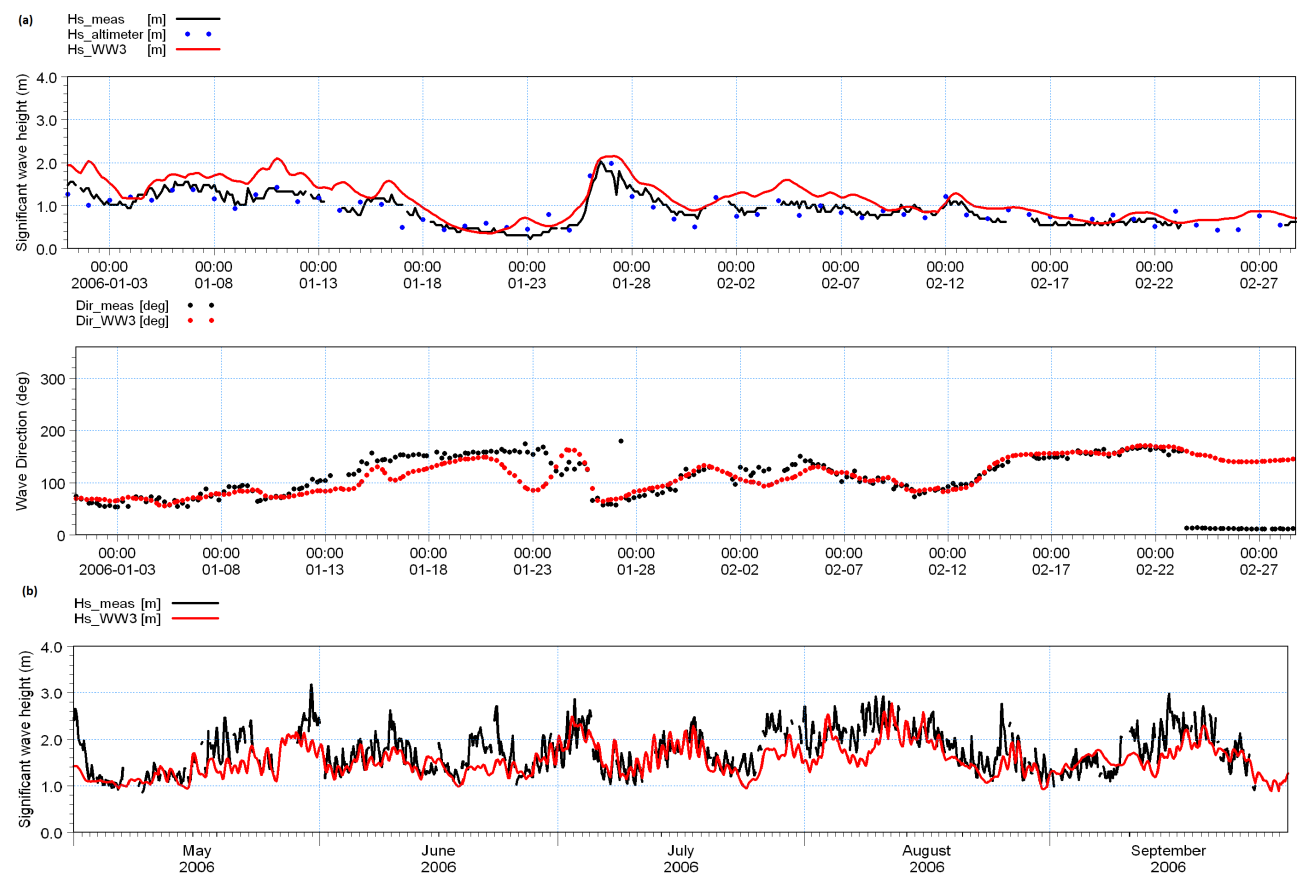

$\begin{gathered}\text { Dir_meas [deg] } \\ \text { Dir-WWw }[\text { deg] }\end{gathered}:$ :

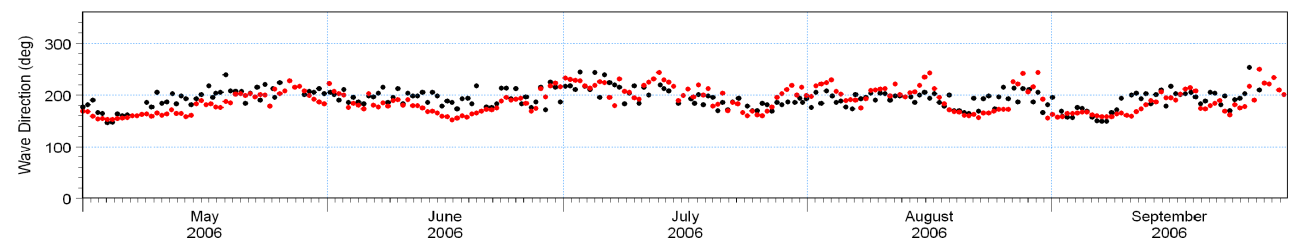

Fig. 3. (a) Comparison between measured (black line) (wave rider buoy) and modelled (red line) wave heights and wave directions for the period January-February 2006 (calm weather season). Altimeter data (blue dots) (deep water: DS5, off Kakinada). (b) Comparison between measured (black line) (wave rider buoy) and modelled (red line) wave heights and wave directions for the period May-September 2006 (rough weather season). (deep water: OB08, off Pondicherry).

Table 1. Statistical parameters for wave height obtained by comparing model results with buoy data at a few locations in the Indian Ocean (January-February 2006).

\begin{tabular}{|c|c|c|c|c|c|c|c|c|c|}
\hline \multirow[t]{2}{*}{ Sr. No } & \multirow[t]{2}{*}{ Buoy ID } & \multicolumn{2}{|c|}{ Location } & \multirow[t]{2}{*}{ Mean (m) } & \multirow[t]{2}{*}{ Bias (m) } & \multirow[t]{2}{*}{ RMS (m) } & \multirow[t]{2}{*}{ Bias/Mean } & \multirow[t]{2}{*}{ SI } & \multirow[t]{2}{*}{ Corr Coefft } \\
\hline & & Long $\left(^{\circ}\right)$ & Lat $\left(^{\circ}\right)$ & & & & & & \\
\hline 1 & DS5 & 83.265 & 14.004 & 0.91 & 0.18 & 0.26 & 0.2 & 0.28 & 0.92 \\
\hline 2 & OB8 & 81.51 & 11.585 & 1.07 & 0.04 & 0.21 & 0.04 & 0.20 & 0.88 \\
\hline 3 & MB10 & 84.98 & 12.541 & 1.09 & 0.22 & 0.31 & 0.2 & 0.28 & 0.87 \\
\hline 4 & SW2 & 71.107 & 16.974 & 0.96 & -0.26 & 0.32 & -0.27 & 0.34 & 0.82 \\
\hline 5 & MB12 & 90.138 & 18.131 & 0.75 & 0.05 & 0.19 & 0.07 & 0.26 & 0.79 \\
\hline 6 & DS2 & 72.407 & 10.684 & 0.88 & -0.07 & 0.19 & -0.08 & 0.21 & 0.56 \\
\hline 7 & DS6 & 72.74 & 8.324 & 0.83 & -0.01 & 0.17 & -0.02 & 0.21 & 0.56 \\
\hline 8 & SW4 & 74.764 & 12.973 & 0.58 & -0.19 & 0.22 & -0.33 & 0.38 & 0.75 \\
\hline 9 & AN4 & 93.556 & 13.416 & 0.69 & -0.23 & 0.32 & -0.33 & 0.46 & 0.64 \\
\hline 10 & AN3 & 91.66 & 10.52 & 1.16 & -0.10 & 0.24 & -0.09 & 0.21 & 0.64 \\
\hline 11 & OB7 & 78.57 & 8.208 & 1.26 & -0.48 & 0.57 & -0.38 & 0.45 & 0.44 \\
\hline 12 & SW5 & 78.233 & 8.709 & 0.75 & -0.19 & 0.33 & -0.25 & 0.41 & 0.21 \\
\hline
\end{tabular}


water as shown in Table 1. Model and buoy comparison for calm season (February 2006) is presented in Fig. 3a and for rough weather (May-September 2006) in Fig. 3b. Irrespective of calm or rough weather, if high-frequency wave signals had been present due to the prevailing winds, the model would have reproduced the same signals.

As WW III is a global model, it provides poor correlation for shallow water waves. It may be noted that both DS2 and DS6 are shallow water buoys and not deep water buoys, even though the nomenclature used is DS instead of SW (deployed off Lakshadweep islands), and that is the reason for obtaining a poor correlation coefficient (Table 1). This shows the need of coupling a global or regional model with a shallow water or nearshore model for receiving accurate shallow water wave prediction. Model wave direction matches very well with the measurements for deep water buoys at both the locations in the Indian Ocean. It may also be noted that SW2 is not a shallow water buoy, but a deep water buoy (water depth $=2000 \mathrm{~m}$ ). It is found that model simulation results match well with the altimeter data for most of the buoy locations in the north Indian Ocean with correlation coefficients ranging from 0.54 to 0.84 (Table 2). As both the model and the altimeter data are accurate for deep water, statistical analysis has not been carried out for the shallow water buoy locations.

\subsection{Propagation of Atlantic Ocean swells in the north Indian Ocean}

A series of very high waves broke over La Réunion island in the Indian Ocean on 12 May 2007, when there was an extreme weather event that occurred off southern tip of South Africa in the Atlantic Ocean. The waves did numerous damages on property and lives of Réunion and neighbouring islands, and the maximum wave height was $11.3 \mathrm{~m}$ and significant wave height $6.4 \mathrm{~m}$. During 14-15 May, the significant wave height was $8.0 \mathrm{~m}$, as measured by wave gauges (http://www.aviso.oceanobs.com). The storm engendered swells, which propagated in the Indian Ocean at about $1000 \mathrm{~km} \mathrm{day}^{-1}$, arrived at Réunion, where low winds do not disrupt the swell. Lasting long enough, and with a rather large extension, it was observed by multiple altimeter tracks. This event that took place in May 2007 affected the north Indian Ocean wave characteristics as the swell heights were very high of the order of $15.0 \mathrm{~m}$ near the generation area. The swells spread their energy as they travelled from the Atlantic Ocean towards the north Indian Ocean.

The present study aims at understanding the propagation of the Atlantic Ocean swells in the north Indian Ocean and their impact on the wave characteristics of the north Indian Ocean. The wave model reproduced the event of May 2007 accurately, and, therefore, we analysed the results of the model to explain the above objective, along with the altimeter wave data. As we do not have in situ measurements during May 2007, we compared the model results with collocated altimeter data. The match is found to be very good near the Réunion island with significant heights ranging from $5.0 \mathrm{~m}$ to $6.0 \mathrm{~m}$. (Figs. 5 and 6). Figure 6 shows the altimeter interpolated data obtained from the merged satellite track data.

It was reported that the Southern Hemisphere has the highest (frequency of occurrence) yearly storms (Alves, 2006). The Indian Ocean wave climate is mainly affected by the swells arriving from the western side, i.e. the eastward propagating swells from the Atlantic Ocean and also from the Southern Hemisphere. The eastward propagating swells from the Atlantic Ocean (off South Africa) spread through the Indian Ocean, reaching the coasts of Thailand, Indonesia and the southwestern Australia. Swells from the Atlantic Ocean are observed throughout the year, propagating towards the north Indian Ocean. Alves (2006) proved that the extratropical areas in the Southern Hemisphere generate robust swell systems that spread energy in the entire global ocean and are a potentially important component of the wave climate in most basins in both the hemispheres. The study of Alves (2006) showed that the swells generated at forties propagate eastward into the tropical and the extratropical latitudes of the Indian Ocean and the Pacific Ocean. In the present study, we find that the extent of swells coming from the Atlantic Ocean, and that they propagate beyond the Equator having more effect in the Bay of Bengal than in the Arabian Sea (Figs. 5 and 6). The model clearly brings out the event of May 2007 that we have seen in the altimeter data. The model results (Fig. 6) show that the swells from the Atlantic Ocean with significant wave heights higher than $15.0 \mathrm{~m}$ were observed near the swell generation area on 10 May 2007 (near southern tip of South Africa), and propagated towards the north Indian Ocean. The swells originated from the southern tip of South Africa started propagating towards Madagascar and hit La Réunion island on 12 May 2007 with significant wave heights reaching up to $6.0 \mathrm{~m}$. When the NCEP Reanalysis wind data (Fig. 7) of 11 and 14 May were checked, we found that two major wind systems prevailed in the Indian Ocean on those days. We could see from the wind plots of 14 May 2007 (Fig. 7) that waves were following the winds. We could clearly find that one swell system travelled to the north Indian Ocean and the other system towards the south Indian Ocean. After reaching the islands, the swells propagated freely into large areas of the north Indian Ocean and the south Indian Ocean (towards Western Australia). We found (Figs. 6e, f and g) that the energy spread towards the Bay of Bengal is higher than that in the Arabian Sea (please refer to Fig. 9; also explained elsewhere). We can also observe that, after the swells hit the islands, major part of the swell energy dissipated and the swell heights reduced to $6.0 \mathrm{~m}$ (Fig. 5). Moreover, after hitting the Islands, the swells changed the direction of propagation from southwest to northeast and travelled towards the Bay of Bengal, and further to Western Australia and Indonesia. 
Table 2. Statistical parameters for wave height obtained by comparing model results with altimeter data at the few buoy locations in the Indian Ocean (January-February 2006).

\begin{tabular}{|c|c|c|c|c|c|c|c|c|c|}
\hline \multirow[t]{2}{*}{ Sr. No } & \multirow[t]{2}{*}{ Buoy ID } & \multicolumn{2}{|c|}{ Location } & \multirow[t]{2}{*}{ Mean (m) } & \multirow[t]{2}{*}{ Bias (m) } & \multirow[t]{2}{*}{ RMS (m) } & \multirow[t]{2}{*}{ Bias/Mean } & \multirow[t]{2}{*}{ SI } & \multirow[t]{2}{*}{ Corr Coefft } \\
\hline & & Long $\left(^{\circ}\right)$ & Lat $\left(^{\circ}\right)$ & & & & & & \\
\hline 1 & DS5 & 83.265 & 14.004 & 0.88 & 0.27 & 0.39 & 0.30 & 0.44 & 0.78 \\
\hline 2 & OB8 & 81.51 & 11.585 & 1.02 & 0.20 & 0.35 & 0.19 & 0.34 & 0.77 \\
\hline 3 & MB10 & 84.98 & 12.541 & 0.98 & 0.40 & 0.47 & 0.41 & 0.48 & 0.84 \\
\hline 4 & SW2 & 71.107 & 16.974 & 0.90 & -0.07 & 0.23 & -0.08 & 0.26 & 0.84 \\
\hline 5 & MB12 & 90.138 & 18.131 & 0.72 & 0.18 & 0.31 & 0.25 & 0.43 & 0.54 \\
\hline
\end{tabular}

$*$ SI $=$ Scatter Index.

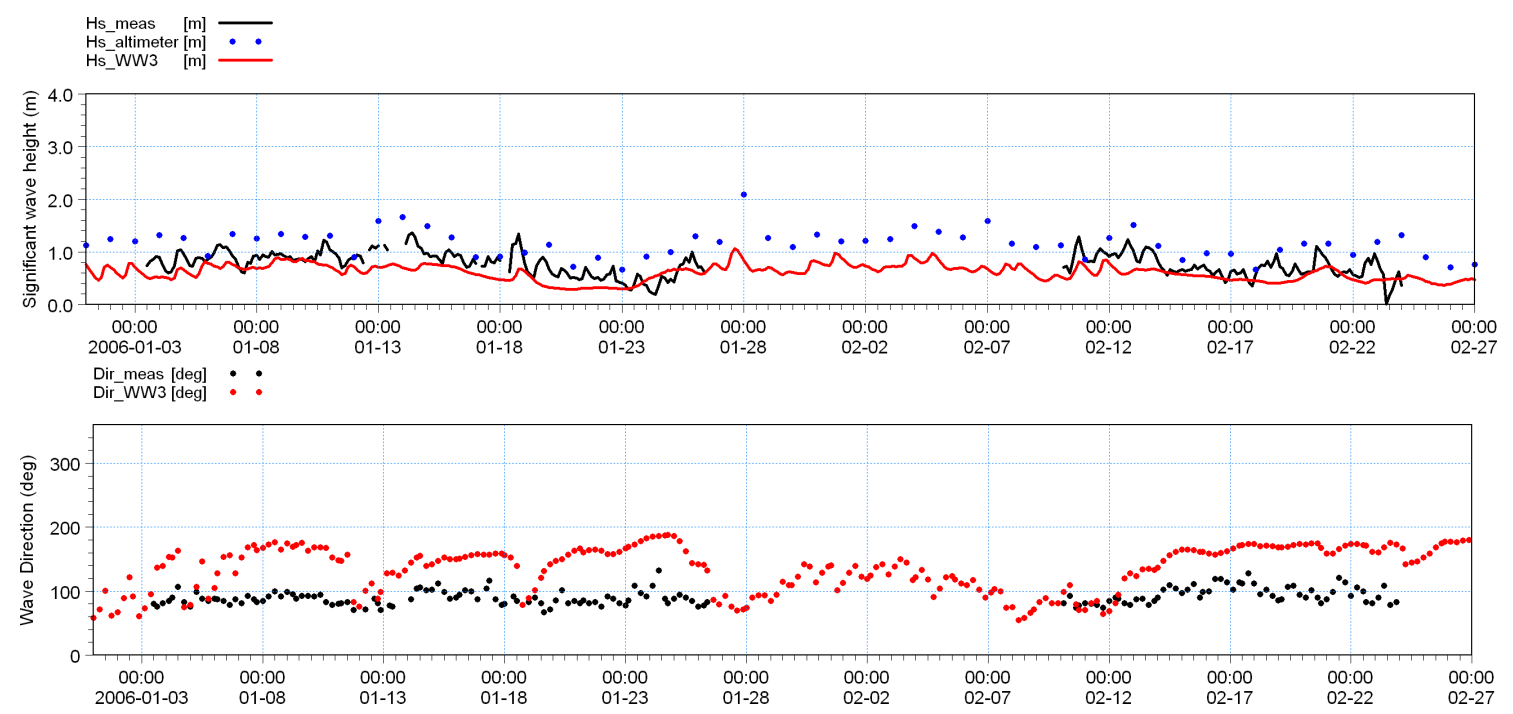

Fig. 4. Comparison between measured (black line) (moored buoy) and modelled (red line) wave heights and wave directions for the period January-February 2006. Altimeter data (blue dots) (shallow water: SW5, off Tuticorin).

In order to study the propagation of swells at different regions in the Indian Ocean, significant wave heights (Fig. 9) were extracted for those regions (Fig. 1a). Figure 7 shows the prevailing wind systems in the Indian Ocean during this event. Near the generation area (P1), the swell significant wave height was $15.0 \mathrm{~m}$ (please refer to the box marked in Fig. 9). As the swells propagated, the magnitude of swell heights decreased along the path P1-P2-P4-P5 due to energy dissipation, whereas, along the path $\mathrm{P} 2-\mathrm{P} 3$, the magnitude increased due to the presence of whirl/eddy winds. Due to this whirl effect, wind energy was added at the point P3. Subsequently, the significant wave height increased to about $18.0 \mathrm{~m}$ (refer to the box marked in Fig. 9). Further, as the swell travelled from P3 to P8 (near southwest Australia), the energy got dissipated, resulting into lower swell heights off southwest Australia. Along the path P1-P2 - La (La Réunion island), swell height decreased from $10.0 \mathrm{~m}$ to $6.0 \mathrm{~m}$.

One of the objectives of the present study is to understand how these swell systems affect the north Indian Ocean wave characteristics. We found that the height of swells decreased along the path P4-P5-P6 due to dissipation of energy, and there was no significant effect of these swells in the Arabian Sea (P6). However, in the Bay of Bengal considerable effect is observed. Initially, swell height decreased (along the path P2-P4-P5), and then increased along the path P5-P7 ( $\mathrm{P} 7$ refers to the Bay of Bengal) due to addition of swell systems as well as wind systems already present in the Bay of Bengal. The observed wind systems in the Bay of Bengal are as follows: one along the path P1-P2-P4-P5-P7, and the other from the west coast of Australia (Fig. 7). Therefore, we find the presence of two significant swell systems in the Bay of Bengal.

Further, spectral analysis was carried out to check the presence of two swell systems in the Bay of Bengal. Figure 8a and $\mathrm{c}$ represent the spectra extracted at the location P1 before and during the event, respectively. Figure $8 \mathrm{~b}$ and d represent the spectra at location $\mathrm{P} 7$ before and during the event. $\mathrm{P} 1$ is the swell generation area, and P7 is the point in the Bay of Bengal, where we extracted the spectra. It can be seen from the figures that, at point P1 before the event occurred, the peak frequency was approximately $0.14 \mathrm{~Hz}$ (Fig. 8a), whereas during the event the peak frequency shifted to less 

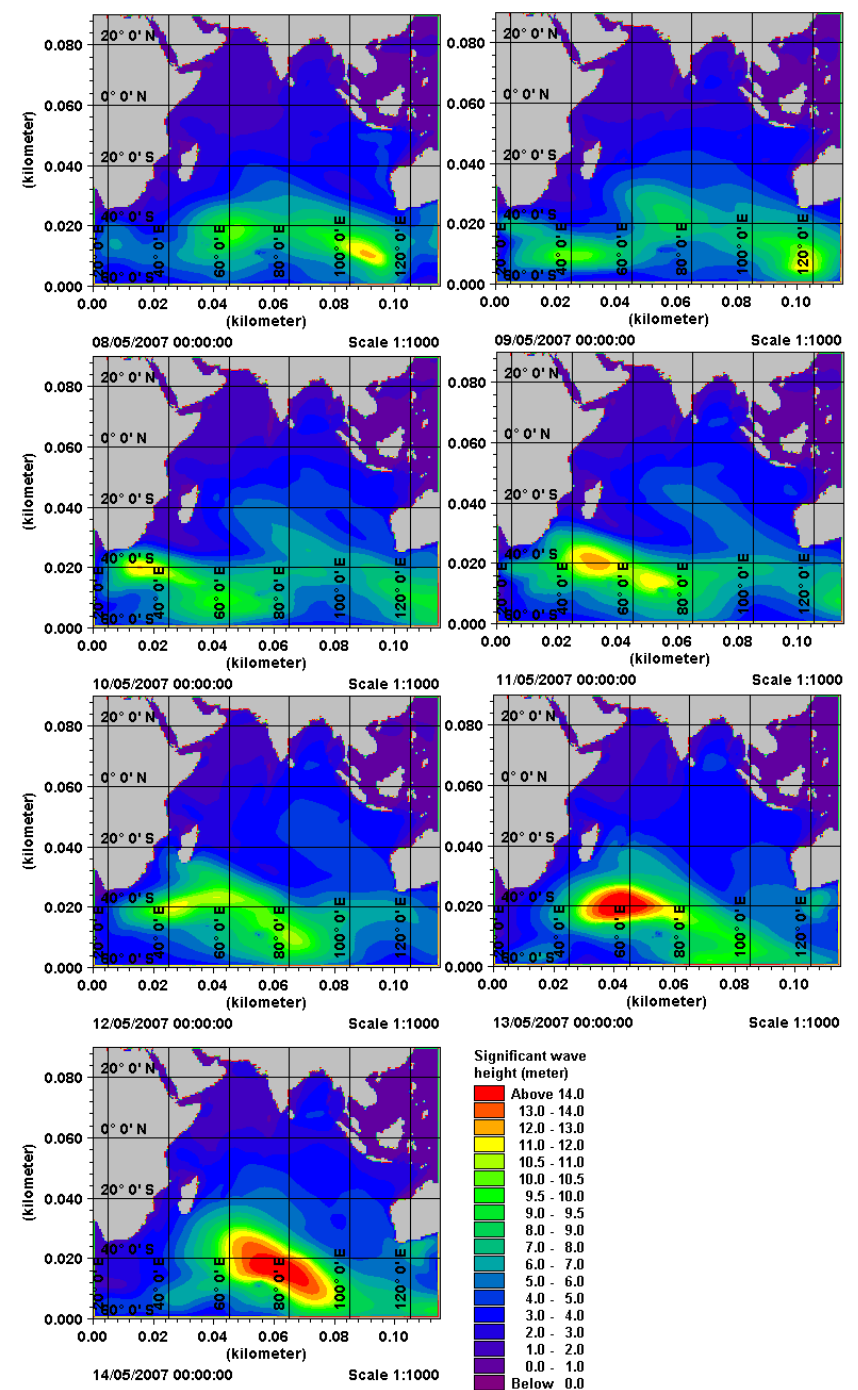

Fig. 5. Propagation of swells during May 2007 in the north Indian Ocean (WW III model).

than $0.1 \mathrm{~Hz}$ (Fig. 8c). Peak frequency remained constant as long as the event persisted, but with change in the energy. Fig. 8d presents two spectral peaks: the one at the low frequency (Peak 1) represents the waves coming from the western Australian region, and the other peak (Peak 2) represents the waves from P1. Our calculation shows that it takes nearly 2.5 days for the swells from $\mathrm{P} 1$ to arrive at $\mathrm{P} 7$.

As the model has been validated for the year 2006 for different buoy locations in the north Indian Ocean (Tables 1 and 2), wave parameters have been extracted at a few locations for May 2007, before, during and after the extreme event. We find that, on an average, $\approx 1.0 \mathrm{~m}$ wave height was noticed at these locations before the extreme event (in the absence of swells), whereas, during the swell propagation, an increment of $1.0 \mathrm{~m}$ to $2.0 \mathrm{~m}$ was observed in the significant wave heights in the Bay of Bengal (P7) (Fig. 9) and an in-
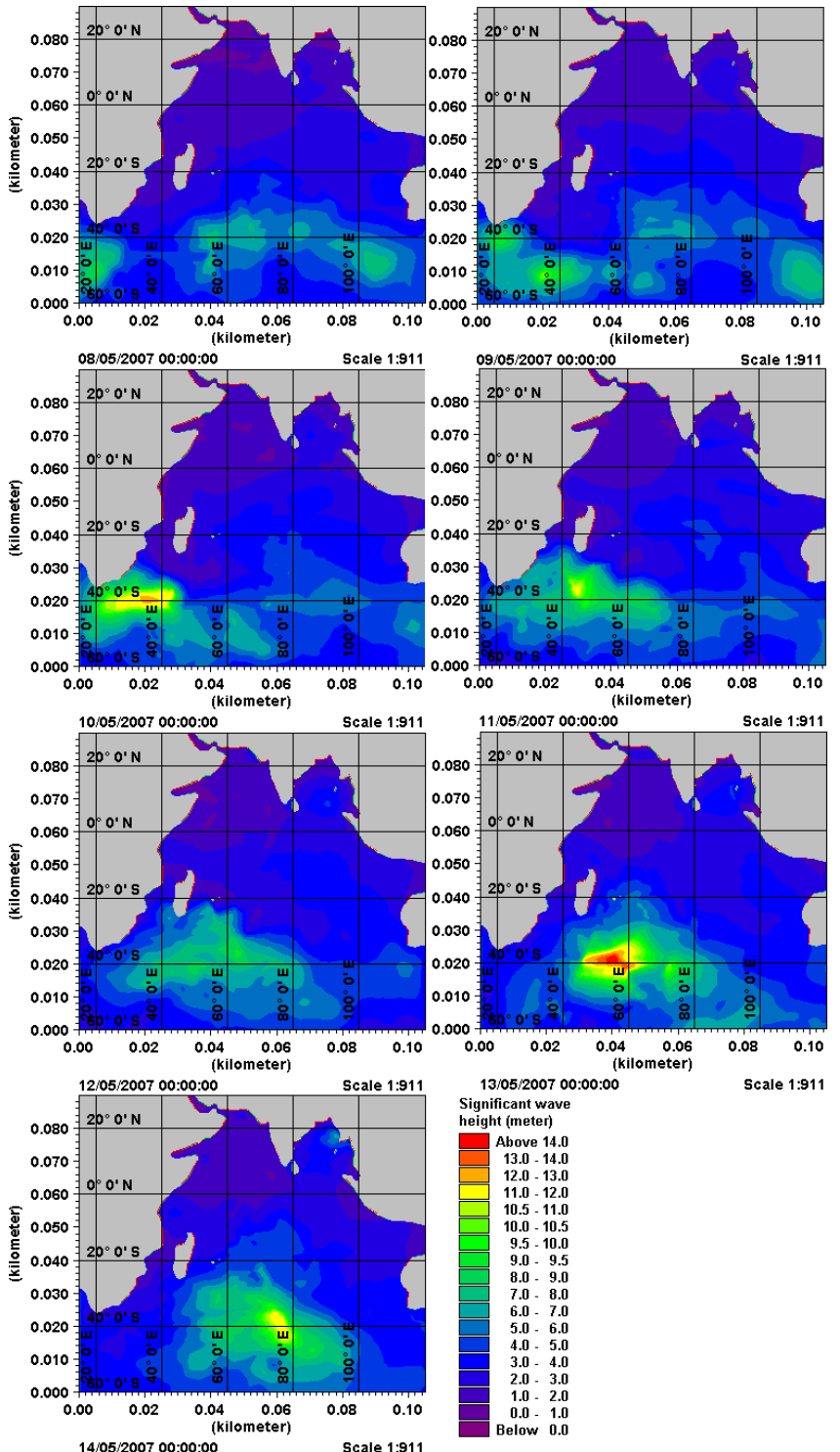

Fig. 6. Propagation of swells during May 2007 in the north Indian Ocean (altimeter data).

crement of $2.0 \mathrm{~m}$ to $3.0 \mathrm{~m}$ off the southern tip of India (P5). After the swells reached the coast of western Australia, they completely lost the energy and the wave heights reduced to the normal heights of $1.0 \mathrm{~m}$ (Fig. 9). However, in the Arabian Sea (P6) during the entire period, only a constant wave height of $1.0 \mathrm{~m}$ existed (Fig. 9). This shows that the Arabian Sea is least affected by the swells generated in the Atlantic Ocean.

The study reveals that the swells generated in the Roaring Forties (between $15^{\circ}$ to $80^{\circ} \mathrm{E}$ longitude) propagate in the SW/SSW direction towards the north Indian Ocean. This happens during pre-monsoon season (February to May) when the large-scale winds are weak, and swells from the south Indian Ocean dominate. During SW monsoon season, 

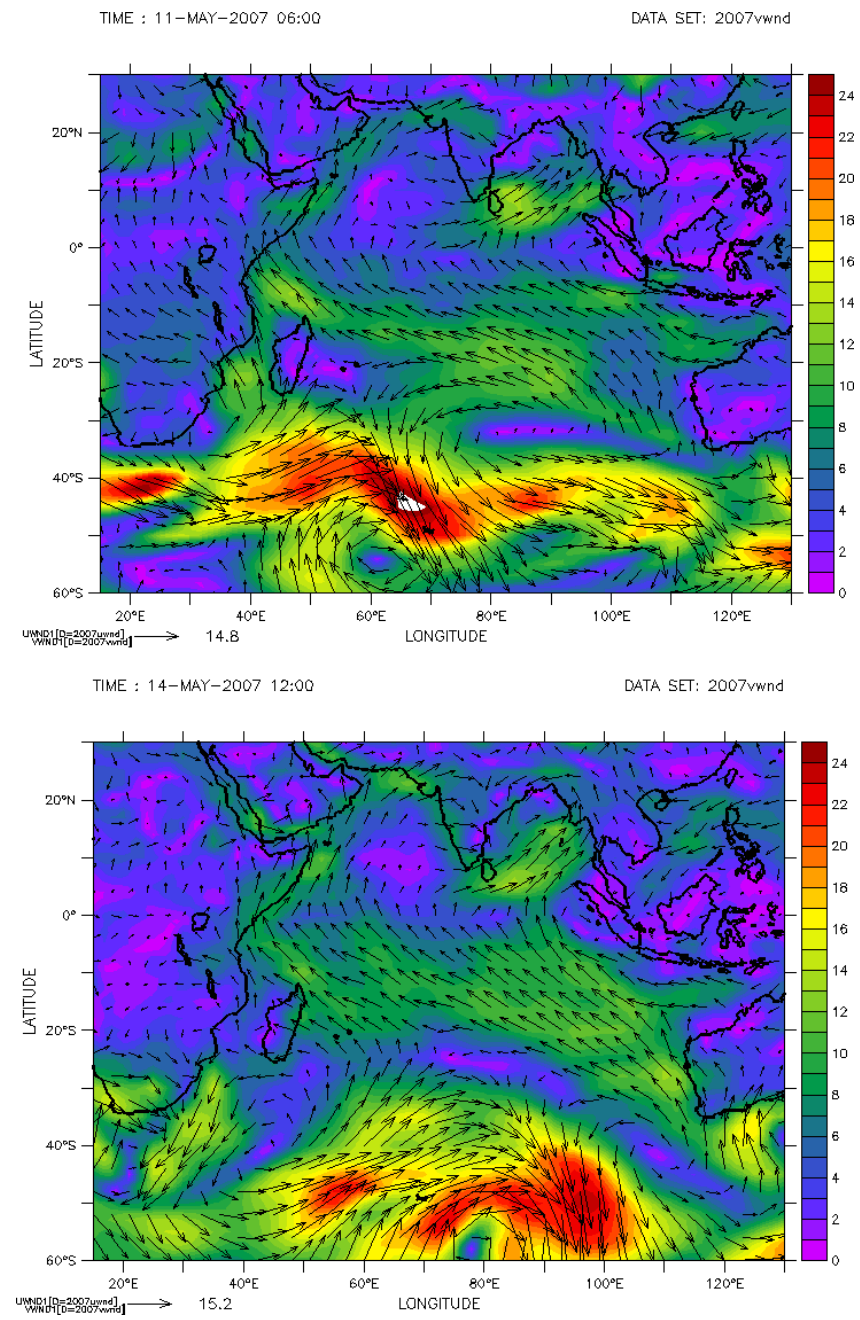

Fig. 7. Major wind systems in the Indian Ocean during May 2007.

the swells are higher in the Arabian Sea than in the Bay of Bengal, because the potential swell generation area is in the Arabian Sea (Aboobacker et al., 2011). On the other hand, during NE monsoon season, NE swells are stronger in the Bay of Bengal than in the Arabian Sea. More quantitative analysis is necessary to understand the effect of south Indian Ocean swells in the Bay of Bengal during northeast monsoon.

\section{Conclusions}

The third-generation wave model WAVEWATCH III has been successfully implemented for the Indian Ocean, and the results are validated with the measurements. The modelled wave parameters show good correlation with the measured data. The propagation of Atlantic Ocean swells during May 2007 event has been successfully reproduced by the wave model, and this has been further confirmed by the merged altimeter significant wave heights. We find that the
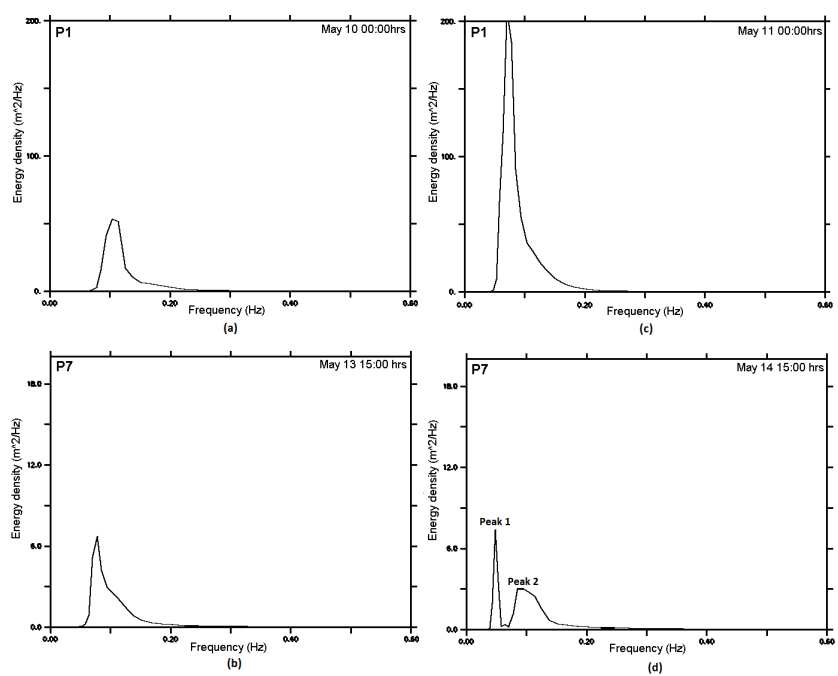

Fig. 8. Typical 2-D energy spectra at two locations P1 and P7 (a) and (b) before and (c) and (d) during the event in May 2007.

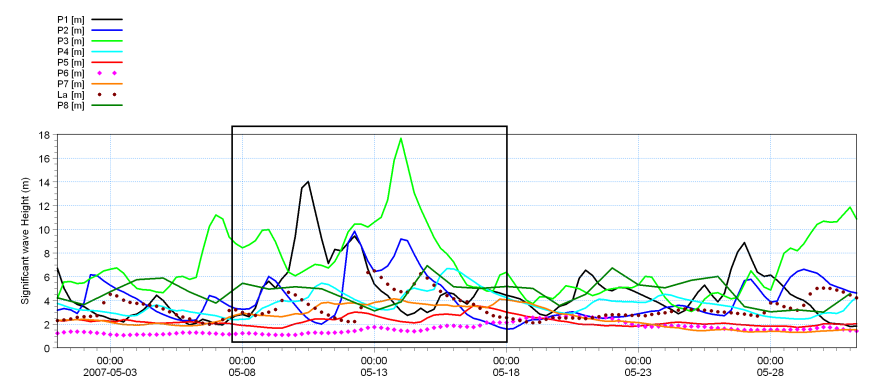

Fig. 9. Significant wave heights at different locations in the Indian Ocean during May 2007 (to describe the impact of south Indian Ocean swells in the Arabian Sea and the Bay of Bengal).

swells generated in the Atlantic Ocean near the southern tip of South Africa propagated towards the north Indian Ocean. The magnitude of swell height was around $15.0 \mathrm{~m}$ (near the generation area) and when it propagated towards the north Indian Ocean reduced to around $6.0 \mathrm{~m}$ (near La Réunion island). Analysis of model results also reveals that wave characteristics of the Arabian Sea are least influenced compared to those of the Bay of Bengal when the Atlantic or the South Indian Ocean swells enter the north Indian Ocean.

Acknowledgements. We thank S. R. Shetye, Director, National Institute of Oceanography (NIO), Goa for his interest in this study. We are grateful to CERSAT, IFREMER, France for providing the required altimeter data and INCOIS, Hyderabad for providing the buoy data for model validation. Authors are thankful to our colleagues for their valuable contributions. The generation of very high swells is reported in the AVISO site. The NIO contribution number is 5267 . 
Edited by: S. Tinti

Reviewed by: two anonymous referees

\section{References}

Aboobacker, V. M., Vethamony, P., Sudheesh, K., and Rupali, S. P.: Spectral characteristics of nearshore waves off Paradip, India during monsoon and extreme events, Nat. Hazards, 49, 311-324, 2009.

Aboobacker, V. M., Rashmi, R., Vethamony, P., and Menon, H. B.: On the dominance of pre-existing swells over wind seas along the west coast of India, Cont. Shelf Res., 31, 1701-1712, doi:10.1016/j.csr.2011.07.010, 2011.

Alves, J.-H. G. M.: Numerical modeling of ocean swell contributions to the global wind-wave climate, Ocean Modell., 11, 98$122,2006$.

Ardhuin, F., Bertrand, C., and Fabrice, C.: Observation of swell dissipation across oceans, Geophys. Res. Lett., 39, 1-5, 2009.

Ardhuin, F., Rogers, E., Babanin, A. V., Filipot, J. F., Magne, R., Roland, A., Westhuysen, A., Queffeulou, P., Lefevre, J. M., Aouf, L., and Collard, F.: Semiempirical Dissipation Source Functions for Ocean Waves, Part I: Definition, Calibration, and Validation, J. Phys. Oceanogr, 40, 1917-1941, 2010.

Barber, N. F. and Ursell, F.: The generation and propagation of ocean waves and swell, I. Wave periods and velocities, Philos. Trans. Roy. Soc. London, 240A, 527-560, 1948.

Bhatt, V., Kumar, R., Basu, S., and Agarwal, V. K.: Assimilation of altimeter significant wave height into a third-generation global spectral wave model, IEEE Trans. Geosci. Rem. Sens., 43, 110$117,2005$.

Bhatt, V., Kumar, R., Basu, S., Sarkar, A., and Agarwal, V. K.: Impact of the Oceansat-1 MSMR winds on analyzed oceanic wind and wave predictions, Ocean Eng., 31, 2283-2294, 2006.

Bhowmick, S., Kumar, R., Chaudhuri, S., and Sarkar, A.: Swell Propagation over Indian Ocean Region, Int. J. Ocean Clim. Sys., 2, 87-99, 2011.

CERSAT: Altimeter \& Microwave Radiometer ERS Products User Manual, C2MUTA01IF, version 2.2, CERSAT, IFREMER, BP 70, 29280 Plouzané, France, 1996.

Chen, Y.-H., Francis, J. A., and Miller, J. R.: Surface temperature of the Arctic: Comparison of TOVS satellite retrievals with surface observations, J. Climate, 15, 3698-3708, doi:10.1175/15200442, 2002.

Donelan, M. A., Drennan, W. M., and Katsaros, K. B.: The airsea momentum flux in conditions of wind sea and swell, J. Phys. Oceanogr, 27, 2087-2099, 1997.

ESA: March, ENVISAT RA-2/MWR Product Handbook. Tech. Rep. PO-TN-ESRRA-0050, 2002.

Francis, P. E. and Stratton, R. A.: Some experiments to investigate the assimilation of Seasat altimeter wave height data into a global wave model, Q. J. R. Meteorol. Soc., 116, 1225-1251, 1990.

Grachev, A. A. and Fairall, C. W.: Upward momentum transfer in the marine boundary layer, J. Phys. Oceanogr., 31, 1698-1711, 2001.

Hanson, J. L. and Phillips, O. M.: Wind Sea Growth and Dissipation in the Open Ocean, J. Phys. Oceanogr., 29, 1633-1648, 1999.

Hanson, J. L. and Phillips, O. M.: Automated analysis of ocean surface directional wave spectra, J. Fluid Mech., 209, 567-589, 2001 .
Kalnay, E., Kanamitsu, R., Kistler, R., Collins, W., Deaven, D., Gandin, L., Iredell, M., Saha, S., White, G., Woollen, J., Zhu, Y., Chelliah, M., Ebsuzaki, W., Higgins, W., Janowiak, J., Mo, K. C., Ropelewski, C., Wang, J., Leetma, A., Reynolds, R., Jenne, R., and Joseph, D.: The NCEP/NCAR 40-Year Reanalysis Project, B. Am. Meteorol. Soc., 77, 437-471, 1996.

Kumar, R., Bhowmick, S. A., Ray, S., Bhatt, V., Surendran, S., Basu, S., Sarkar, A., and Agarwal, V. K.: Improvement of predictability of waves over Indian Ocean, Nat. Hazards, 49, 275291, 2009.

Lionello, P., Gunther, H., and Janssen, P. A. E. M.: Assimilation of altimeter data in a global third-generation wave model, J. Geophy. Res., 97, 14453-14474, 1992.

Munk, W. H.: Tracking storms by forerunners of swell, J. Meterol., 4, 45-57, 1947.

Muraleedharan, G., Mourani Sinha, A. D., Rao, N., Unnikrishnan, N., and Kurup, P. G.: Estimation of wave period statistics using numerical coastal wave model, Nat. Hazards, 49, 165-186, 2009.

Naval Oceanographic Office, NOAA Laboratory for Satellite Altimetry, March: GEOSAT Follow-On GDR User's Handbook. Tech. Rep. OAA/NESDIS/ORA:E/RA31, 1315 East-West Highway 3620, Silver Spring, MD, USA, 2002.

Picot, N., Case, K., Desai, S., and Vincent, P.: PODAAC User Handbook. IGDR and GDR Jason products, Tech. Rep. SMM-MUM5-OP-13184-CN (AVISO), JPL D-21352 (PODAAC), 2003.

Polnikov, V. G., Dymov, V. I., Pasechnik, T. A., Lavrenov, I. V., and Abuzyarov, Y. N.: Real merits of the wind wave model with an optimized source function, Doklady Earth Sciences, Moscow: Pleiades Publishing Ltd., 1375-1379, 2007.

Queffeulou, P.: Long term quality status of wave height and wind speed measurements from satellite altimeters, Proceedings of the ISOPE conference, Honolulu, Hawaii, USA, 2003.

Queffeulou, P.: Long term validation of wave height measurements from altimeters, Mar. Geodynam., 27, 495-510, 2004.

Rajesh, P. R., Joseph, J. K., and Chaudhury, R. R.: Modeling of wave characteristics in north Indian Ocean, Proceedings of International Conference in Ocean Engineering, ICOE 2009, 1-5 Feb, IIT Madras, 1-10, 2009.

Semedo, A., Saetra, O., Rutgersson, A., Kahma, K. K., and Pettersson, H.: Wave-induced wind in the marine boundary layer, J. Atmos. Sci., 66, 2256-2271, 2009.

Snodgrass, F. E., Groves, G. W., Hasselmann, K. F., Miller, G. R., Munk, W. H., and Powers, W. M.: Propagation of swell across the Pacific, Philos. Trans. R. Soc. London, A259, 431-497, 1966.

Swain, J., Prasada Rao, C. V. K., and Venkitachalam, N. R.: Performance evaluation of third generation wave model for the Indian Ocean region using analysed winds. Proceedings of METOC, 56 February 2004, 207-216, 2004.

SWAMP Group: Sea Wave Modelling Project (SWAMP): An intercomparison study of wind wave prediction models, Part-1: Principal results and conclusions, Ocean Wave Modell., Plenum Press, 256 pp., 1985.

Tolman, H. L.: User manual and system documentation of WAVEWATCH-III version 1.15, NOAA/NWS/NCEP/OMB. Tech. Note, 151, 97 pp., 1997.

Tolman, H. L.: Validation of NCEP's Ocean winds for the use in wind wave models, Global Atmos. Ocean Sys., 6, 243-268, 1998a. 
Tolman, H. L.: Validation of a new global wave forecast system at NCEP, in: Ocean Wave Measurements and Analysis, edited by: Edge, B. L. and Helmsley, J. M., ASCE, 777-786, 1998b.

Tolman, H. L.: User manual and system documentation of WAVEWATCH III version 1.18, NOAA/NWS/NCEP/OMB, Tech. Note 166, 110 pp., 1999.

Tolman, H. L.: User manual and system documentation of WAVEWATCH-III version 2.22, NOAA/NWS/ NCEP/OMB Technical Note 222, 133 pp., 2002a.

Tolman, H. L.: Validation of WAVEWATCH III version 1.15 for a global domain. NOAA/NWS/NCEP/OMB Technical Note No. 213, 33 pp., $2002 b$.

Tolman, H. L.: Treatment of unresolved islands and ice in wind wave models, Ocean Model, 5, 219-231, 2003.

Tolman, H. L. and Chalikov, D. V.: Source terms in a thirdgeneration wind-wave model, J. Phys. Oceanogr, 26, 2497-2518, 1996.
Vethamony, P., Rao, L. V. G., Kumar, R., Sarkar, A., Mohan, M., Sudheesh, K., and Karthikeyan, S. B.: Wave climatology of the Indian Ocean derived from altimetry and wave model, Proc. PORSEC, Goa, India, 301-304, 2000.

Vethamony, P., Sudheesh, K., Rupali, S. P., Babu, M. T., Jayakumar, S., Saran, A. K., Basu, S. K., Kumar, R., and Sarkar, A.: Wave modeling for north Indian Ocean using MSMR analyzed wind, Int. J. Remote Sens., 27, 3767-3780, 2006.

Vledder, G.: Extension of the discrete interaction approximation for putting nonlinear quadruplet wave-wave interactions in operational wave models, 4th ASCE International Symp. Ocean Waves, Meas. Anal., San Francisco, CA, 540-549, 2001.

WAMDI Group: The WAM model - a third generation ocean wave prediction model, J. Phys. Oceanogr., 18, 1775-1810, 1988.

WISE: The WISE Group: Wave Modelling - The state of the art, Progr.Oceanogr., 75, 603-674, 2007. 